\title{
CONTEMPORARY AFRICA THROUGH THE THEORY OF LOUIS DUMONT
}

Man does not only think, he acts. He has not only ideas, but values.

LOUIS DUMONT

If there is one thing on which scholars of contemporary Africa agree, it is that the continent is, perhaps now more than ever, a difficult place to understand ${ }^{\mathrm{I}}$ In some of the most prominent studies to emerge in recent years, this is said to be true not only for analysts, but for the people who live in Africa, as well. As established social and cultural systems are dismantled, as poverty increases, and life expectancy shortens, people across the continent find themselves living in a "shadow world" (Ferguson, 2006: I5), a "no man's land" (see Guyer, 20I I), marked by a "generalized condition of semiotic suspension" (Apter, 2005: 283) in which words and actions "no longer correspond to the social interweave as we tend to conceptualize and experience it" (de Boeck \& Plissart, 2004: 34).

In moving quickly through these few descriptions of contemporary Africa - and I have given only a few, it is not hard to find others - I do not wish to make light of the fact that the last thirty years have been marked by significant suffering for people across the continent. Many of those who live in Zambia, the country I know best, have endured considerable hardship as a result of the privatization of industry and the shrinking of the welfare state, particularly as these have unfolded alongside the AIDS pandemic and the most recent global financial crisis. My contention in this paper is therefore not that analyses focused on the corrosive effects of "neoliberalism and other social diseases" (Richland, 2009) are mistaken in noting that economic change has challenged relational life or cultural practices. Rather, what concerns me here 
is the social science that follows from this conclusion. It is one thing to point out the confusion that results from weakened social, economic, and political institutions; it is quite another to assert that this confusion now takes the analytical place once occupied by social organization.

My goal in this article is to outline a framework for analysis that I believe addresses the question of social organization in contemporary Africa more thoroughly than many current studies have been able to do, while at the same time foregrounding the challenges that the neoliberal period has posed to social life on the continent. The central task of this endeavor is highlighting the relational forms that people consider to be most important. More specifically, a salient point in studies from the region is that hierarchy is a key aspect of social life that has been undermined by liberalization, broadly defined (e.g. Ferguson, 20I3; Hickel, 20I5; Smith, 2007; Haynes \& Hickel, 20I6; Scherz, 20I4). I argue that hierarchy is a central social structural form in Southern Africa, and probably elsewhere on the continent as well. I also argue that the reason that hierarchy is so central is because it is connected to key cultural values, and herein lies the theoretical underpinning of my argument.

In short, the model I am proposing is a reading of urban African social life indebted primarily to Louis Dumont (1980, I983, I986) and focused on the relationship between social forms or structures on the one hand and ideas or ideology on the other. I present this approach through an analysis of Pentecostal Christianity on the Zambian Copperbelt. In this article, I will show that although Pentecostal believers have a model of how two key religious ideas charisma and prosperity - ought to relate to each other, the circumstances of their religious practice make it difficult for them to keep these ideas, and the social forms that reflect them, in what they consider to be their proper position.

The main theoretical problem of this paper is therefore the primary question of Dumont's work as well - namely, as I have just noted, how it is that ideas and social structures are related. For Dumont, answering this question means starting with ideology, which, at least in his work on India, meant starting with religion. However, for our purposes, what is more important than his identification of the ideological with the religious is his emphasis on what he calls the "unitary thought" that orders a society (Dumont, I983: 24). In Dumont's India this is, famously, the opposition of purity and impurity. Dumont puts this discussion of ideology alongside an analysis of social structures by showing how various social forms are ranked based on their capacity to articulate the central ideological tension. Therefore, again taking up his model, the structure or social form that best articulates the opposition of purity and impurity is a hierarchically-arranged whole, i.e., the caste system. It is because of its relationship to ideology that the hierarchical whole becomes the most important social form in Dumont's India. 
This connection between social structures and ideology is made most clear in what Dumont calls the "paramount value," or the "the preeminent value by which [a society] is animated" (Dumont, I986: 23I). Dumont only identifies two paramount values, which he refers to as holism and individualism; I am sure that there are others, but his examples will suffice for now. Holism is the paramount value in those societies where the whole is the most important social form, whereas, unsurprisingly perhaps, individualism is the paramount value in those societies where the individual - "the independent, autonomous, and thus essentially non-social moral being" (Dumont, I986: 25), as Dumont nicely puts it - occupies this position. To say that the whole or the individual represents the most important social form in a given society is not just to say that it is given precedence, as in, for example, the liberal notion that the rights of the individual trump those of the group. Rather, the superior position given to the social form indicated by the paramount value means that all sorts of things - actions, institutions, and ideas - are organized in such a way as to promote the production of, for example, individuals or hierarchical wholes (see Robbins, I994). Although the paramount value is therefore related to a particular social form, the two are not the same. On the contrary, the paramount value is an expression of what a society considers to be most important, the articulation of a particular ideological opposition in and with a particular social structure.

So far, we have identified the role of ideology in ordering social forms. We have also hinted at the parallel role of these social forms in ordering a range of other elements. Lastly, we have situated this process under the umbrella of the paramount value. In order to animate all these pieces of the model, it is necessary to take an additional step, which brings us to one of the most important aspects of Dumont's theory: value. In incorporating this concept into my discussion, I have found it helpful to make a distinction between the noun "value" or "values" and the verb "to value" (see Haynes, 20r7; Haynes \& Hickel, 20I6). It is this latter notion that I am interested in here.

For Dumont, the process of valuing is necessarily relational - that is, things are valued in relation to one another. This means that, as he puts it, "to adopt a value is to introduce hierarchy" (Dumont I980: 20). As we have already seen, what ranks one social form higher than another is its superior capacity to articulate key ideological elements. The process of transforming a set of social forms into a ranked order, i.e., valuing them, is therefore worked out in terms of ideology. Once this process is in motion, it quickly applies in what we might think of as the other direction. That is, the social form that has become the most important structures, in turn, ideas, and indeed a whole range of cultural elements, including actions, institutions, and practices (Robbins, 2009). Social forms are therefore valued in relation to a central ideological opposition or framework, a "unitary thought," while ideas are valued in relation to the 
social form that best articulates that thought. Incidentally, I think this process helps us to see why Dumont offers what feels like such a capacious definition of values - note the use of the plural noun - which includes not only ideas, but also actions and, indeed, social forms (e.g. "Affinity as a value" (Dumont, I983)), as in his work each of these represents an element ranked in the way I have just outlined.

In Dumont's theory, then, I think we can treat value as a process that applies to all aspects of a society and is worked out at the point of articulation between ideology and social forms. My use of the term "articulation" here is meant to denote both interconnection and vocalization, as Dumont's theory of social forms reveals - I am tempted to say, "announces" - ideology and vice versa. This process is seen most clearly in the paramount value, which represents a fusion of ideology and social forms, or perhaps more precisely, social forms as ideologically significant. Ideology here serves as a starting point, but we could debate whether it is always necessary to start there; certainly, we should question whether doing so requires us to privilege religion in the way that Dumont does in his work on India. In any case, I hope I have made it clear that once this process is in motion, the movement is always back and forth, as ideas rank social forms, which, in turn, rank ideas.

I would like to suggest that this intersection, this passing back and forth across a point of articulation, represents the great strength of Dumont's theory. It is also the reason why I find Dumont to be particularly useful in examining contemporary African social life, to wit, when we animate his work in this way and thus place a strong emphasis on process, we also introduce the possibility of failure. In other words, even though the organization of social forms and ideas reflect each other, either or both of their ranking could be disrupted. People may not always achieve the social form they value most; they may not always prevent certain ideas from usurping others they consider to be more important. This is true in part because of the internal variations always present in the systems Dumont describes, as is clear, for example, in his work on what he calls "marriage alliance" in South Asia (Dumont, I983).

In addition, interference with the ranking of ideas and social forms may stem from the fact that, as Marshall Sahlins puts it, "the whole is a part" (see Sahlins, 20I0). That is, while people have a model of how the elements of their society ought to be ranked - what I refer to below as the "social ideal" - this model is vulnerable to all sorts of forces emerging from outside their community. Here we can include ideas or ideologies, such as Christianity or capitalism in the modern West, as Dumont shows in his later work (Dumont I977, I986). As my discussion of the Zambian Copperbelt will show, disruption of the social ideal may also be a result of external forces that act on the other side of our model - that is, that challenge the structure of the social form that people consider to be most important. 
This potential for failure in turn necessitates all sorts of social, as well as ideological, work - what Achille Mbembe, in a discussion that turns our attention back to contemporary Africa, calls "the labor involved in making life possible" (Shipley, 2010: 659). More broadly, then, what this article represents is an analysis of people's efforts to produce a particular kind of social outcome. In this way, my discussion fits within what Joel Robbins (2013) has recently referred to as "the anthropology of the good," that is, an anthropology of how people work to create what they understand to be a moral, or right, or desirable social world. In urban Zambia, this process is bound up with social asymmetry, indeed, hierarchy, which is the topic we turn to now.

\section{MOVING AS THE COPPERBELT PARAMOUNT VALUE}

The context for my discussion is a Copperbelt community that I call Nsofu, which is a township located on the outskirts of the city of Kitwe. Nsofu is a community of approximately 25,000 people. It is densely populated, a mixture of privatized company housing and homes built through a government "site and service" scheme, some of which are still under construction. It is also an economically diverse place. A number of my informants were employed in the formal sector, while many others made a living through what is locally glossed as "business," or trade, often informal, in such diverse goods as frilly children's dresses from South Africa, dried fish from Zambia's Northern Province, or shoes from as far away as Dubai. Finally, there are those in Nsofu who have no regular income and survive on piecework, the good graces of others, or some combination of the two.

If we were to identify an orienting, "unitary thought" on the Copperbelt, I think the strongest candidate is what I have elsewhere called "moving" (Haynes, 20I7). Briefly, moving refers to measurable personal advancement, first and foremost in the form of economic status, but also with regard to progress through the lifecourse, as well as educational and professional achievement. In the view of Pentecostals, moving happens "by the Spirit," as believers develop with regard to the two key Pentecostal values of charisma and prosperity, which I discuss in more detail below. Moving must be evident to others, who find evidence that someone is moving in an expanding waistline, a new suit or mobile phone, or a Toyota sedan parked in front of someone's house (see Guyer, 2004: I47). It is important to note that although moving is experienced by individual persons or households, it can only come about as a result of social relationships. No one moves on her own - indeed, appearing to do so would subject a person to accusations of Satanism - but instead advances through the assistance provided by a network of relationships.

Mentioning the relational aspects of moving makes it easy to see how this idea shapes social structures. People on the Copperbelt move through a variety of social ties, but the unifying trait that all these relationships possess 
is hierarchy, and more specifically socioeconomic hierarchy. Most common here are patron-client relationships marked by enduring "dependence" (Ferguson, 20I3). These long-term social bonds link people of higher economic status to people of lower economic status, who depend on their patrons for access to resources, money, and connections that can help them to move. It is the difference in status between patrons and clients that makes moving happen in these relationships. A connection to a person who is more highly positioned on the social ladder enables that person to pull someone up in a way that he could not if he were on the same "rung," so to speak. And the person who is pulled up in this way is also pulling someone else along, since ties of dependence concatenate to produce long chains through which, at least ideally, everyone can move. This stair-stepped social world therefore not only articulates the central Copperbelt value of moving, but also provides a condition of its possibility.

By identifying hierarchical relationships as the most important social forms on the Copperbelt, we have made our first pass over the point of articulation that is at the heart of our discussion here. In the remainder of this article, I would like to turn this analysis in the opposite direction, moving back across the intersection we are examining to explore how social forms, especially hierarchy, rank other cultural elements, in this case, religious ideas or values. Turning this corner of the argument will bring us to some more robust ethnography. In what follows we will keep hierarchy in the foreground by examining how it is worked out among Pentecostal believers in Nsofu.

\section{PENTECOSTAL ASYMMETRY AND MOVING BY THE SPIRIT}

In his study of Ghanaian Pentecostalism, Paul Gifford (2004) writes that the believers he observed flocked to pastors known for their spiritual gifts, especially prophecy and exorcism. It is these religious services, he argues, and not the promise of social ties with fellow believers that bring people into Accra's many Pentecostal churches. As Gifford puts it, in these congregations "the links are all vertically towards the prophet, rather than horizontally between followers (Gifford, 2004: I08)." I found a similar pattern in Pentecostal churches in Nsofu. Like most neighborhoods in urban Zambia, Nsofu is home to dozens of churches, most of which are locally-initiated Pentecostal congregations with fewer than Ioo members. When asked where they go to church (Mupepa kwi?, literally, "Where do you pray?"), many Pentecostal believers would respond the way I expected them to, that is, by giving the name of one of these churches: Higher Calling, Bethlehem Pentecostal, Power and Glory, and so on. However, I found that a significant minority would answer this question not with the name of a group, but rather with the name of a pastor, for example, "I pray with Pastor Phiri" (na/kuli Pastor Phiri). 
This preference for identification with a particular leader, rather than a Pentecostal congregation, illustrates the importance of a pastor, evangelist, or prophet in the religious participation of Nsofu believers. On the Copperbelt, the central Pentecostals relational tie is between a layperson and a pastor (see Haynes, 2013), an asymmetrical relationship that is often likened to and described as the tie between a parent (bafyashi) and a child. The import of this relationship is well illustrated in the case of Pastor Ephraim, a church leader who became a Pentecostal after a brief period of service in the Methodist Church. Pastor Ephraim was known throughout Nsofu as a prophet, and his popularity was reflected in the rapid growth of his congregation, Freedom Bible Church. Like many Pentecostal churches on the Copperbelt, Freedom Bible Church held services in a rented government schoolroom. Each Sunday, believers pack into narrow desks for prayer, singing, and preaching; many also attend midweek meetings in private homes. Although the congregation had several designated leaders, Pastor Ephraim was the one who attracted the most attention, and when he did not show up at a midweek prayer meeting, those in attendance were visibly disappointed.

The relationship between Pastor Ephraim and his followers is representative of the tie that most Pentecostal leaders on the Copperbelt have to the lay members of their churches. Ordinary believers pursue ties with pastors because they want to gain access to spiritual services that they hope will solve their problems. In this case, the members of Freedom Bible Church expected that Pastor Ephraim's powerful prayer would help them get jobs; his prophetic divination would show them if a relative was bewitching them; his skill in deliverance would break the demonic powers that kept them from conceiving. Testimonies to these various ends circulated widely in Nsofu, fueling Pastor Ephraim's popularity. As a result, more and more people flocked to his meetings or to see him in his home for private consultation, hoping that their prayers would also be answered because of a connection to this powerful "man of God."

According to my informants, Pastor Ephraim's power as a result of divine "favor" or "grace"; in what follows, I bring these descriptions together under the heading of "charisma." To a certain extent, my use of this term follows Weber's definition (I946: 245-264): Pastor Ephraim's power was supernatural, understood by Pentecostals to come from the Holy Spirit (umupashi wamushilo). However, the difference between people like Pastor Ephraim and ordinary believers is one of degree rather than kind, as the divine power that the former display is the same as that which is (at least in principle) available to everyone, but has been given in greater measure to those who become pastors or prophets. Thus, while all believers pray, the prayers of people like Pastor Ephraim are understood to be particularly effective; while all believers feel that God sometimes provides them with insight or direction, the prophecies of special men of God are deemed especially trustworthy. 
The fact that commitment to a particular pastor follows from a desire to address one's common, everyday problems turns our attention to another aspect of Copperbelt Pentecostalism: the prosperity gospel. Also known as the "faith gospel" or "health and wealth gospel," the prosperity gospel is a Christian movement, familiar to many in anthropology, that turns on the notion that it is God's will for all believers to be rich, healthy, and successful (see Hunt, 2000 for a survey). The prosperity gospel has been one of the driving forces behind the exponential expansion of Pentecostalism across the Global South, and here Zambia is no exception (Cheyeka, 2008). This movement has shaped Christian practice throughout the country, influencing both Pentecostal and non-Pentecostal churches. Despite the unmistakable impact of the prosperity gospel on the Copperbelt, however, the teachings of this movement have not been unproblematically incorporated into local Pentecostal practice.

When I first arrived in Nsofu, I told people that I was especially keen to study prosperity gospel churches. Although it was clear that they knew what I was referring to by this request, and could often even identify certain pastors that they felt fit the prosperity gospel profile, for the most part these were not the churches that the believers I spoke to attended. In fact, not only were they not part of these congregations, some of these believers spoke of prosperity gospel churches with palpable distain. However, although Pentecostals in Nsofu were clearly wary of these overt expressions of the prosperity gospel, that is, of churches where this teaching represented the main attraction, this did not mean that the idea that God wanted Christians to experience material success did not figure in believers' theology. On the contrary, every Pentecostal that I met in Nsofu would say that they believed it was God's will for Christians to prosper, and that they expected that eventually this would be true of them. All the same, they could not abide congregations where the prosperity gospel occupied a central position.

My informant's wariness regarding the prosperity gospel puts it in tension with the charisma we have already seen to be the primary factor in religious participation in the Copperbelt. That these two ideas exist in opposition is evident in the expectations believers had of their religious leaders. On the one hand, Pentecostals thought it appropriate for pastors to display markers of material wealth: dressing smartly, carrying thick leather-bound Bibles, and wielding high-tech mobile phones. In keeping with this expectation, leaders known for their charismatic gifts would sometimes also hold themselves up as examples of prosperity. Pastor Ephraim, for instance, was never seen in anything other than a crisp shirt and tie, and almost always wore a suit as well. Additionally, in his sermons he would refer to purchases of new clothing or prestige goods, including items bought at the Hotel Edinburgh, one of the fancier establishments in Kitwe. 
Despite the importance of these indexes of success, however, they are not by themselves the reason that believers seek to develop relationships with preachers and prophets. As we have seen, the attraction of church leaders lies first and foremost in their religious skill. Pastors who effectively manage prosperity, always keeping it subordinated to charisma, can expect to draw a large crowd; those who cannot maintain this balance, but instead allow prosperity to get the upper hand, open themselves up to disparaging comments from believers, not to mention other pastors. The marginal influence of preachers associated primarily with the prosperity gospel is probably why, in the hundreds of Pentecostal events I have attended on the Copperbelt over the last decade, I have almost never seen a pastor whose preaching and ministry were characterized by prosperity alone.

I hope I have made it clear that prosperity and charisma represent two key religious ideas among Copperbelt Pentecostals. I also hope that my discussion has shown that Nsofu believers are very concerned with keeping prosperity subordinate to charisma in their churches and, especially, in the visible testimony of their leaders. The question remains however, of why it is that one of these ideas must rank more highly than the other. Both prosperity and charisma produce hierarchies of success, in the first instance, and spiritual strength, in the second. In this way, each of these ideas promotes the social form people on the Copperbelt consider to be most important. The issue, then, is how that social form pushes back on these ideas. More specifically, if ideas are ranked or valued in relation to social structures, that is, if ideas become recognizable as values - how does that happen in this case? Responding to this question requires us to briefly examine how charisma and prosperity relate to the hierarchy that we have identified as the most important social form on the Copperbelt, and more specifically how it has been affected by the recent economic history of the region.

\section{THE PROBLEM WITH PROSPERITY}

Over the course of the last three decades, various shocks to the Zambian economy, including the global financial crisis that struck during my doctoral fieldwork in 2008 and 2009, have made it difficult for people in communities like Nsofu to maintain a social world structured by material status. This is because unemployment and underemployment push more people toward the bottom of the Copperbelt economic gradient, leaving fewer opportunities for relationships of productive dependence, while increasing the risk that hierarchy will be exploitative (cf. Ferguson, 2013). These same factors, along with others, like currency devaluations, also make it harder to acquire the prestige goods that serve as key status-markers in this system (Haynes, 2012). Taken together, these external influences put considerable pressure on and sometimes effectively destroy the social form that people on the Copperbelt consider to be most important. 
By itself, the prosperity gospel does not do much to improve this situation. Even if the attraction of a religious movement that promises wealth is obvious, particularly as other mechanisms for economic advancement break down, it should also be clear that the prosperity gospel does little to repair the damage wreaked by the economic crisis on the economic hierarchy. All the prosperity gospel can do is attempt to produce the same structure via supernatural, rather than market, means (cf. Comaroff \& Comaroff, I 999). In contrast to prosperity, charisma has the distinct advantage of producing hierarchies that do not depend on the market, but are instead a result of ritual life and the mysterious work of the Holy Spirit (Haynes, 20I5). On the Copperbelt, this means that charismatic hierarchy appears to be much more stable than economic hierarchy, be it the conventional or the prosperity gospel variety thereof. In other words, when it comes to establishing hierarchy, charisma is better at it than prosperity. Importantly, charismatic hierarchy also offers analogues of dependence and moving, in this case worked out in terms of religious assistance and aspiration. The details of these ideas are discussed elsewhere (see Haynes, 20I7: 57-73), yet the example of leaders like Pastor Ephraim provide enough of a sense of religious dependence.

My aim in highlighting the social importance of charismatic asymmetry for Nsofu believers is to draw attention to the way that key social forms order ideas. Again, these are the social forms that people value most and represent local notions of a good society. In this case, the importance of hierarchy on the Copperbelt means that that charisma, which makes better hierarchies than prosperity, is the more highly ranked of the two ideas. The fact that hierarchy structures the relative positions of charisma and prosperity among Copperbelt Pentecostals does not, however, mean that believers are always successful in keeping these ideas in what they would consider to be their proper order. Rather, there are several points at which this process can and does break down, a brief outline of a few of these is provided below.

One of the most serious threats to ranking charisma above prosperity is found in the theological structure of the latter. As mentioned earlier, the central tenet of the prosperity gospel is that Christians should be wealthy. The way that followers of the prosperity gospel are supposed to access divine blessings is through displays of faith - giving gifts, especially when they can't afford to, or telling family and friends that something they are hoping for will happen, even if they cannot be sure that it will. God is then expected to act in keeping with (ukulingana) a believer's faith; in the words of the New Testament, "He who sows sparingly will also reap sparingly, he who sows generously will also reap generously" (2 Corinthians 9: 6). Great faith - that is, great spiritual strength - is said to produce a great earthly reward. The troubling aspect of all of this for Copperbelt Pentecostals is not difficult to see: in the framework of the prosperity gospel, charisma and prosperity are one in the same thing. While, as we 
have seen, believers want charisma to rank higher than prosperity, the religious mechanisms of the prosperity gospel continually undermine the ordering of these ideas. In addition to these theological problems, Pentecostals are also faced with the fact that church leaders rely on laypeople for economic support and are therefore often forced to be rather strategic in the relationships they form among ordinary believers (Haynes, 20I5). I won't go into the specifics of this problem here, but suffice it to say that when the primary site of charismatic hierarchy, the tie between leaders and laypeople, is affected by economic concerns, it becomes very difficult for believers to tell whether their pastors and co-parishioners have kept charisma in the right place relative to material prosperity.

Faced with these problems, it is not surprising that when leaders demonstrate only charisma without any emphasis on prosperity, they very quickly attract a large following. In the case of a young prophet who rose to prominence just before I left the field in 2009, the overwhelming presence of charisma in his ministry made the group that gathered around him something of an island of clarity in the ongoing conflict between charisma and prosperity. I first hear of this prophet from several informants who had visited his meetings or, in some cases, been given reports of his powerful ministry by their Pentecostal friends. Those who had not yet gone to see him were anxious to do so, and when a few informants planned a visit I jumped at the chance to tag along. We had been told that because of the prophet's popularity we should arrive very early at the home where his followers met if we wanted to see him. This home was located in a community a short distance from Nsofu, a township comprised of dozens of identical white bungalows that had once been employee accommodation for the mine power company. While it might have been difficult to find one house among so many that looked alike, we had no trouble locating our destination. From far up the street we could hear the unmistakable sound of Pentecostal prayer as believers raised their voices in dozens of individual petitions. As we drew closer we could see a number of women crowded at the windows and doors of a house bursting at the seams; still others had found seats on the grass, their heads shielded from the sun by spare citenge wrap skirts or blankets that a few hours earlier had swaddled babies against the morning chill (Figure I). Because the prophet's services were in such high demand, the believers who hosted the meeting had devised a system to help ensure that all those who wished to meet with him privately would be able to do so. A small box had been filled with cardboard squares, each marked with a number. Different days of the week were allocated to each of the surrounding townships and on the designated day residents of those communities were invited to take a number and wait their turn for individual consultations (Figure 2). 

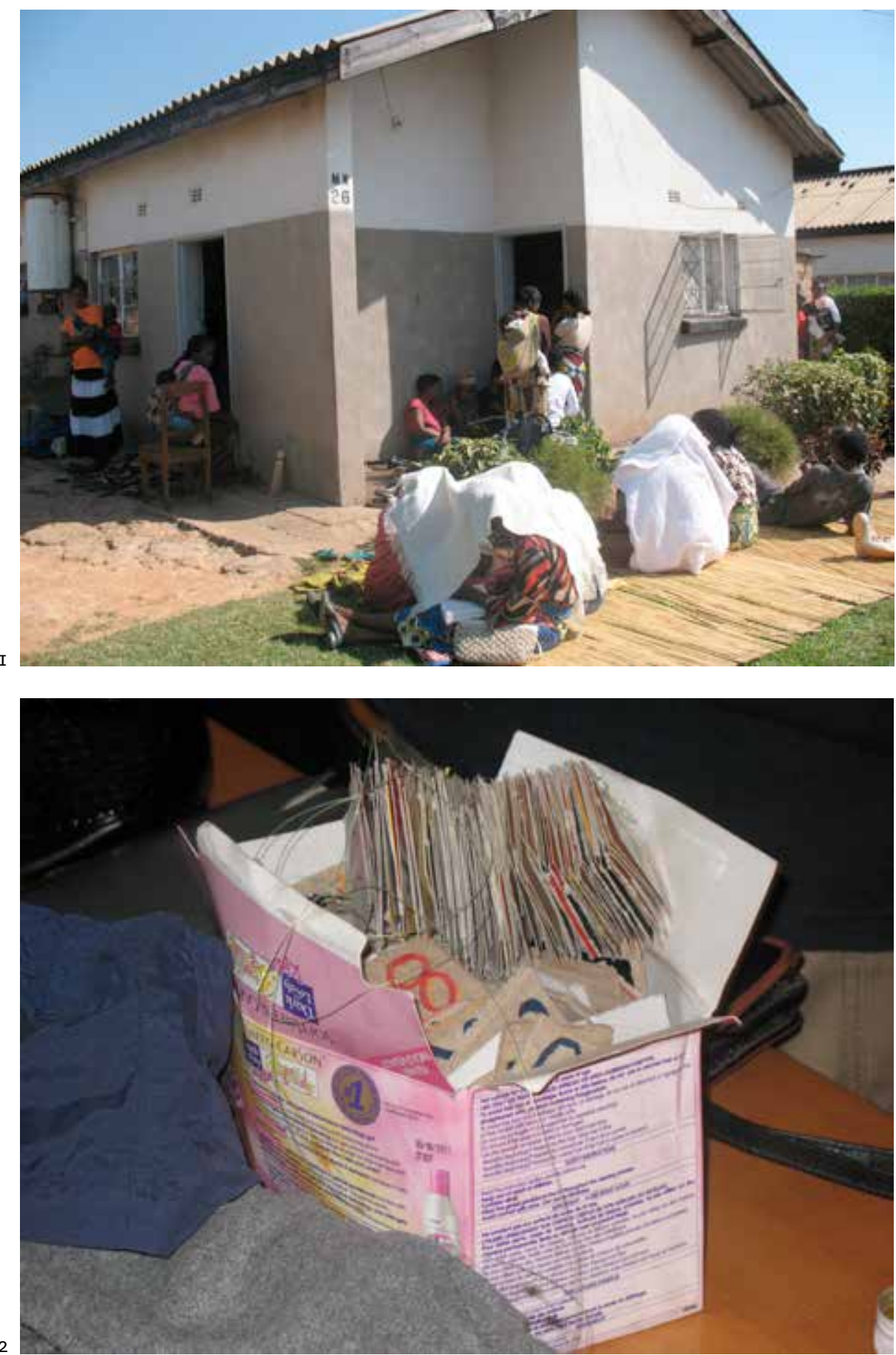
Despite his obvious popularity, the humility of this prophet was evident in many ways. First, rather than employ a title such as Pastor, Prophet, or Evangelist, a practice common among up-and-coming Pentecostal leaders, he was instead known by the simple teknonym of Bashi Jethro. Where others would have taken care to be smartly dressed in a suit or trendy jeans, Bashi Jethro wore a T-shirt and loose trousers. Unlike other church leaders, who occasionally received believers in their homes, Bashi Jethro preached in the sitting room of a local widow. This suggested that his house was not large or well furnished enough for him to receive guests, and that he was therefore dependent on others' wealth for his ministry. Despite these markers of humility and low material status, the power Bashi Jethro displayed in casting out demons and, I was told, in divining spiritual problems during private consultation, was unmistak able to believers. In other words, Bashi Jethro's authority was one based on charisma alone, without any accompanying markers of prosperity.

I mention Bashi Jethro here primarily to offer one final illustration of the importance of charisma for Copperbelt Pentecostals. During my fieldwork, leaders like Bashi Jethro would appear periodically and in a short time amass a large following, which meant that every so often I would find myself with others crowding into a sitting room with several dozen believers, all of them hoping to meet with the new pastor individually. I would argue that the reason figures like Bashi Jethro are so popular is because they represent pure charisma. While leaders that represent prosperity alone are objects of scorn, those who stand for pure charisma are revered by all believers. This, I think, is because these charismatic figures perform a reorienting function: in the ongoing tension between charisma and prosperity, they offer a clear statement of which idea is the more important (Robbins, 20I5).

Although figures like Bashi Jethro appear on the Nsofu religious scene from time to time, and their presence sheds further light on the relative importance of charisma and prosperity on the Copperbelt, I must emphasize that they are the exception, rather than the rule. Most pastors and believers are trying to balance both charisma and prosperity. Moreover, I would argue that the interplay between these two ideas is the hallmark of Pentecostalism in urban Zambia. People have not abandoned prosperity completely, although, as we will see, they have taken steps to reshape it. I think there are several reasons for the ongoing influence of prosperity on the Copperbelt. For one thing, people would like prosperity; more specifically, they would like the kind of prosperity that would create a stable material hierarchy within which they could make moving happen. It stands to reason, then, that if the prosperity gospel were better at making good on its promises, believers would not worry so much about keeping it subordinate to charisma. Together, the possibility that prosperity could rank higher than charisma if it made better hierarchies and the fact that this has not happened, point to the centrality, indeed, the ordering force, of 
hierarchy in urban Zambia. Thus, while people certainly want prosperity, this is only true provided it does not come at the expense of the social forms they consider to be most important. This, then, is what I have in mind when I say that social forms structure, rank, and ultimately value ideas.

By showing that Pentecostals on the Copperbelt have an ideal model of how social forms and ideas ought to relate to each other, I put forward an approach to this model through an analysis of each of these types of elements. Finally, my analysis demonstrates that the process of bringing social life in line with this model can break down. In closing, I would like to return briefly to the issue of breakdown to respond to the reports of chaotic Africa with which I opened my discussion.

\section{CONCLUSION: ON THE “DELIBERATE LABOR” OF MAKING LIFE POSSIBLE}

On one level, my analysis of the Copperbelt has pointed to the same sorts of conclusions reached by those who see contemporary Africa as a place where, to quote James Ferguson, "much is unknown, hard to make out, perhaps even unknowable" (Ferguson, 2006: I5-I6). We have seen in the foregoing discussion how the instability that has followed economic crisis and structural adjustment has eroded a key social form, in this case, socioeconomic hierarchy. Insofar as this is the case, we could say that the Copperbelt has indeed become a difficult place for people to live as they wished. This does not, however, mean that it is a difficult place for them to understand. By showing how the social forms they consider to be most important are tied up in an ongoing process of ranking, or of valuation involving a whole range of ideas and, as in the case of the church, institutions, we can see that the social and relational challenges of late capitalism are not the end of the story. Rather, what the example of Nsofu demonstrates is that Pentecostals are involved in an ongoing process of social and ideological work, to invoke Mbembe again, the "deliberate labor" of everyday life (Shipley, 2010: 657).

In closing, allow me to give just two brief examples that illustrate this kind of labor, one from each axis of the model I have been working with here. First, ideological work. In the case of Copperbelt Pentecostalism, prosperity has undergone some significant redefinition when compared to its transnational counterparts (cf. Haynes, 20I2). Believers in Nsofu have, over time, developed what some of them described in English as a "holistic" understanding of prosperity - one that includes spiritual growth and strong family ties alongside material wellbeing. Although I am sure that this retooling of the prosperity gospel has in part followed from the simple fact that it does not work the way its proponents say it will, when considering it in the context of the relationship that Pentecostal practice has to hierarchy, I think we can safely say that these changes also represent ideological work on the part of people who are trying 
to create a certain kind of social world. If prosperity could be indexed by things other than material goods, then perhaps it could be made to produce hierarchies that do not depend on the market. As the foregoing discussion suggests, I do not think the prosperity gospel has been made to serve this purpose, at least not yet; I do think, however, that we can understand the retooling of its message as an instance of ideological work shaped by the local arrangement of values.

Secondly, I'd like to consider work with regard to social forms. Here we might include the way that Pentecostals try to protect relationships between church leaders and laypeople from being unduly influenced by economic concerns. One example of this from my fieldwork was the incredible lengths that a group of lay leaders went to in order to keep their pastor from knowing how much money different members of the church had contributed toward a large gift given to her on the occasion of her "kitchen mending" party (see Haynes, 20I7, chapter 7). When efforts such as these fail, and often they do, believers continue to engage in the relational work of protecting charismatic hierarchy by voting with their feet, that is, by leaving churches they perceive as having been compromised and joining congregations that appear to value charisma over prosperity in their relational framework. Taken together, these actions represent the social work of people on the Copperbelt to protect the social form they consider to be most important.

While the type of analysis I have outlined here highlights the challenges of contemporary Africa, I hope that I have also shown that doing so requires more than a simple acknowledgement that economic liberalization, let alone any of the other features of neoliberalism, makes it difficult for people to live out their social lives in the same way they always have. By pulling out the interrelated ideas and social forms that together make up local notions of a good society, we are able to see not only those points where these notions fail to match up with reality, but more importantly the continued salience of these notions and the deliberate labor in which people across the continent are engaged in order to bring them about. This Dumontian framework represents a particularly helpful way of approaching contemporary Africa, by acknowledging that ours is a challenging time, but not reducing our time to these challenges. 


\section{NOTE}

I An earlier version of this paper was presented in the social anthropology department seminar at the University of Edinburgh. Thanks to seminar participants, in particular Jonathan Spencer, for their engagement with the paper. Thanks also to Joel Robbins for his feedback on earlier drafts. Any shortcomings in the final version are ultimately my own. My research has been funded by the Wenner-Gren Foundation, a Fulbright-Hayes Doctoral Dissertation Research Abroad grant, the British Academy, and the Carnegie Trust for the Universities of Scotland. Thanks to these organizations for their invaluable support.

Naomi Haynes received her PhD in 2012 from the University of California, San Diego and is currently a Chancellor's Fellow in Social Anthropology at the University of Edinburgh. Her research interests include the Anthropology of Christianity, political economy, exchange, gender, hierarchy, and value. Her monograph, Moving by the Spirit (University of California Press), explores the social life of Pentecostal congregations on the Zambia Copperbelt, paying special attention to the opportunities and struggles associated with spiritual patronage. She has recently begun a new research project on Christian nationalism, which brings together political philosophy, media studies, and congregational ethnography to explore Zambia's constitutional declaration that it is a "Christian nation." 


\section{BIBLIOGRAPHY}

Apter, Andrew H. (2005). The Pan-African nation: oil and the spectacle of culture in Nigeria. Chicago: University of Chicago Press.

Cheyeka, Austin M. (2008). Toward a history of the Charismatic churches in post-colonial Zambia. In: Gewald, J.-B.; Hinfelaar, M. \& Macola, G. (eds.). One Zambia, many histories: towards a history of post-colonial Zambia. Leiden: Brill.

Comaroff, Jean \& Comaroff, John. (I999). Occult economies and the violence of abstraction: notes from the South African postcolony. American Ethnologist, 26/2, p. 279-303. de Boeck, Filip \& Plissart, Marie-Françoise. (2004). Kinshasa: tales of the invisible city. Ghent: Ludion.

Dumont, Louis. (1986). Essays on individualism: modern ideology in anthropological perspective. Chicago: University of Chicago Press.

Dumont, Louis. (1983). Affinity as a value: marriage alliance in South India, with comparative essays on Australia. Chicago: University of Chicago Press.

Dumont, Louis. (1980). Homo hierarchicus: the caste system and its implications. Complete rev. English ed. Chicago: University of Chicago Press.

Dumont, Louis. (1977). From Mandeville to Marx: the genesis and triumph of economic ideology. Chicago: University of Chicago Press.

Ferguson, James. (2013). Declarations of Dependence: Labor, Personhood, and Welfare in Southern Africa. Journal of the Royal Anthropological Institute, 19/2, p. 223-242.

Ferguson, James. (2006). Global shadows: Africa in the neoliberal world order. Durham N.C.: Duke University Press.

Gifford, Paul. (2004). Ghana's new Christianity: Pentecostalism in a globalizing African economy. Bloomington: Indiana University Press.

Guyer, Jane I. (20II). Describing urban 'no man's land' in Africa. Africa, 8I/3, p. 474-492.

Guyer, Jane I. (2004). Marginal gains : monetary transactions in Atlantic Africa, The Lewis Henry Morgan lectures. Chicago: University of Chicago Press. 
Haynes, Naomi. (2017). Moving by the Spirit: Pentecostal social life on the Zambian Copperbelt. Berkeley: University of California Press.

Haynes, Naomi. (2015). Egalitarianism and hierarchy in Copperbelt religious practice: on the social work of Pentecostal ritual. Religion, 45/2, p. 273-292.

Haynes, Naomi. (2013). On the Potential and Problems of Pentecostal Exchange. American Anthropologist, I I5/I, p. 85-95. Haynes, Naomi. (2012). Pentecostalism and the morality of money: prosperity, inequality, and religious sociality on the Zambian Copperbelt. Journal of the Royal Anthropological Institute, I8/I, p. I23-I39.

Haynes, Naomi \& Hickel, Jason. (2016). Introduction: hierarchy, values, and the value of hierarchy. Social Analysis $60 / 4$, p. I-20.

Hickel, Jason. (20I5). Democracy as social death: the making of anti-liberal politics in neoliberal South Africa. Berkeley: University of California Press.

Hunt, Stephen. (2000). 'Winning ways': globalisation and the impact of the health and wealth gospel. Journal of Contemporary Religion, I5/3, p. 33I-347.

Richland, Justin B. (2009). On neoliberalism and other social diseases: the 2008 sociocultural Anthropology year in review. American anthropologist, III/2, p. I70-I76.

Robbins, Joel. (20I7). Ritual, value, and example: on the perfection of cultural representations. Journal of the Royal Anthropological Institute, 2I/SI, p. I8-29.

Robbins, Joel. (2013). Beyond the suffering subject: toward an anthropology of the good. Journal of the Royal Anthropological Institute 19/3, p. 447-462.

Robbins, Joel. (2009). Conversion, hierarchy, and cultural change: value and syncretism in the globalization of Pentecostal and Charismatic Christianity. In: Rio, K. M. \& Smedal, O. H. (eds.). Hierarchy: persistence and transformation in social formations. New York: Berghahn Books.

Robbins, Joel. (I994). Equality as a value: ideology in Dumont, Melanesia, and the West. Social Analysis, 36, p. 21-70. Sahlins, Marshall. (2010). The whole is a part: intercultural politics of order and change. In: Otto, T. \& Bubandt, 
N. (eds.). Experiments in holism: theory and practice in contemporary anthropology. Malden, MA: Wiley-Blackwell.

Scherz, China. (2014). Having people, having heart: charity, sustainable development, and problems of dependence in Central Uganda. Chicago: University of Chicago Press.

Shipley, Jesse Weaver. (2010). Africa in theory: A conversation between Jean Comaroff and Achille Mbembe. Anthropological Quarterly, 83/3, p. 653-678.

Smith, Daniel Jordan. (2007). A culture of corruption : everyday deception and popular discontent in Nigeria. Princeton: Princeton University Press.

Weber, Max. (1946). From Max Weber: essays in sociology. Translated by H. H. Gerth and C. W. Mills. New York: Oxford University Press. 


\section{A ÁFRICA CONTEMPORÂNEA NA PERSPECTIVA DE LOUIS DUMONT}

Resumo

Este artigo responde a uma tendência dos estudos antropológicos recentes na África de enfatizar em demasia a carência de organização social como decorrente do avanço das reformas neoliberais no continente. Fazendo uso de um aparato teórico informado pela teoria de Louis Dumont, demonstro como a organização social continua a ser um tópico analítico importante em tempos de crise - e que isso é mais bem percebido por meio de uma análise dos valores. O foco etnográfico é o cristianismo pentecostal tal como praticado no Cinturão do Cobre da Zâmbia. Nesse contexto africano específico, o pentecostalismo é animado por um valor abrangente que chamo de "avanço" (moving), que abriga dois subvalores: carisma e prosperidade. A análise do modo como os crentes pentecostais lidam com a relação hierárquica entre esses dois subvalores permite uma visão mais clara do mundo social que a adesão ao pentecostalismo torna possível.

\section{CONTEMPORARY AFRICA THROUGH THE} THEORY OF LOUIS DUMONT
Abstract
This article responds to a trend in recent anthropological scholarship in Africa that has overemphasized a lack of social organization following the advancement of neolib- eral reforms across the continent. Using a theoretical framework informed by the theory of Louis Dumont, I show that social organization remains an important analytical topic in times of crisis, and that this is best apprehended through an analysis of values. The ethnographic focus of this article is Pentecostal Christianity as it is practiced on the Zambian Copperbelt. In this particular African context, Pentecostalism is animated by an overarching value that I call "moving," which is in turn made up to two sub-values: charisma and prosperity. By exploring how Pentecostal be- lievers navigate the hierarchical relationship between these two sub-values, we are given a clear picture of the social world that Pentecostal adherence makes possible.

Palavras-chave

Louis Dumont;

valor;

hierarquia; pentecostalismo; Zâmbia.

\section{Keywords}

Louis Dumont; value; hierarchy; Pentecostalism; Zambia. 